changes in nuclear size and cytoplasmic appearance in the periodic acid-Schiff-positive cells in the pituitary which elaborate thyrotrophic hormone.

Regeneration in amphibians was the subject of two reports. Prof. F. E. Lehmann (Bern) reviewed a large body of work on the effects of substances inhibiting regeneration in the anuran tail. Many substances, including amino-acid analogues and colchicine, inhibit regeneration without causing cell death. Not all, however, are effective at all periods of the regeneration process. Thus colchicine is only effective during the period immediately following amputation, aminoketones act in the middle phase of blastema formation, and imino-benzo-quinones affect the later phase of growth and differentiation. Cathep. sin activity normally rises during early regeneration, to reach a peak after about seven days; this peak may occur later in the presence of certain inhibitors. E. M. Deuchar has shown that cathepsin activity rises in both blastema and stump, although it is higher in the former than the latter.

Dr. D. R. Newth (London) reported that urodele and anuran larvæ, with tails made defective by the earlier removal of presumptive tail material, could none the less regenerate normal tails where the plane of amputation lay proximal to the defective region. Where the plane of amputation passed through a part of the tail lacking dorsal or ventral fin the regenerate lacked the appropriate fin. Supernumerary limbs induced in urodele larvæ by nasal placode were frequently hyper- or hypo-dactylous. On amputation they tended to be replaced by more nearly normal limbs, although the restoration of normality might require a further amputation and regeneration.

The conference owed everything to the presence of so many participants from outside Great Britain. British embryologists, in particular, have reason to be grateful to the help given by the Wellcome Trust, the Science Council of Japan and the British Council in making the attendance of many of their foreign colleagues possible. The conference as a whole was indebted to the Royal Society for financial aid.

D. R. NEwTH

\section{LABORATORY ANIMALS BUREAU CONGRESS}

$\mathrm{E}^{\mathrm{A}}$ ACH year for the past decade the Laboratory Animals Bureau has organized a congress of animal and laboratory technicians. This year the congress, which since 1950 has been a two-day affair, was held in Edinburgh during April 4-5 at the Royal (Dick) School of Veterinary Studies. More than two hundred technicians from all parts of Great Britain and Northern Ireland were present, providing a record attendance.

Prof. J. H. Gaddum opened the congress. $\mathrm{He}$ directed attention to the vital part played by the animal technician in the research team and deplored the tendency in some quarters for technicians to call themselves technologists. Technologists were a different type of person, not necessarily a superior type. The technician, and in this particular context, the animal technician, had his own place and dignity.

As is usual at these congresses, all the papers but one were presented by technicians. Mr. C. R. Kennedy spoke of the uses of animals in toxicology, especially of some of the practical problems involved. It is refreshing for those whose work involves use of animals, but who are not often called upon to give the physical day-to-day care that animals demand, to know what the experiment looks like when seen from the animal room. Unsuspected details of husbandry, nearly always taken for granted by the experimenter, become matters of considerable importance and even significant sources of variation in experimental procedures.

Mr. F. Hoyland, speaking on the care and health of guinea pigs, demonstrated from the records of his own laboratory the substantial economies that can be effected, first, by the choice of healthy - in this case accredited-guinea pigs and, secondly, by a high standard of care both before and during experimental treatment. Mr. Ian Samuel, of the Moredun Institute, ranged over the wide field of tolerated infections in laboratory animals. A cursory acquaintance with this problem is sufficient to show that the demand for 'infection-free' animals is seldom, if ever, likely to be met, short of using germ-free animals, which introduces problems of its own. A more useful conception, which has been gaining ground in Britain and receiving particular attention in the United States, is that of the 'specific-pathogen-free' animal (to borrow the American phrase). Most experimenters are not really interested in being assured that their animals are free from all possible pathogens, but most of them want to be assured that no pathogens which can cause intercurrent losses are present in thoir stock, and some want to go a little further and make sure that their animals are free of certain other infections which might interfere specifically with their own work.

On the second morning, Mr. R. J. C. Stewart gave a largely reminiscent paper on the dog's place in medical research, bringing back to life some memories of the late Sir Edward Mellanby. Mr. D. L. MeLean, reporting on the incidence of cedema in the young guinea pig, described work being done in Aberdeen on this condition in guinea pigs that has been seen in recent years and has so far kept its etiology a close secret. It appears that epidemic oedema may be due to soil contamination of the grass meal used in a particular diet always associated with this condition. Mr. G. K. A. Smith produced some data of his own about the blood picture in common laboratory rodents. Finally, Dr. H. E. Lewis gave a review of alimentation in a number of common laboratory species.

On the afternoon of the first day, visits were paid to the Moredun Institute and the Veterinary Laboratory at Lasswade; and to the Small Animal Breeding Station and the Institute of Animal Genetics at the University of Edinburgh. On the second afternoon a visit was arranged to the Zoological Park.

There are two things worth noting about these congresses. The first is that about the same number of technicians, a little more than two hundred, come year after year. Since most of them have their fares and subsistence paid by their employers, it must be presumed that their employers regard their attendance as of some value. 'The second point is that each year new speakers among the technicians are found to present papers, but the standard of papers shows no tendency whatever to fall; an indication of the talent, to a large extent latent, among animal technicians. No other country in the world has meetings of this kind, meetings which belong peculiarly to the 
technicians themselves. There is an obvious connexion between this and the fact that we have good reason in Britain to be proud of the standard of care we give our laboratory animals.

It is a commonplace that experimental biologists are becoming more and more exacting in their demands for quality in experimental animals. This quality cannot be achieved without first-class and well-trained animal technicians. Arrangements already exist in many parts of Britain for courses of instruction for animal technicians, and all this is good. It was strikingly noticeable at the Edinburgh Congress that the lower ranks of the animal technicians are now being recruited from younger boys and girls. There was a considerable number of recent school-leavers. This too is all to the good, provided they are of a type well suited to this particular work. We cannot, however, hope to attract to this sort of work the type best suited to it unless we can offer them the prospect of a good career. A career means adopting a discipline, accepting a training and ultimately achieving a worthy standing among one's fellows.

Here we come right up against an educational problem that is all too common. Entrance to many careers is governed from the age of eleven onwards by the ability to clear a series of educational hurdles. The idea is, of course, to weed out at an early stage those who are not studious or intelligent enough to benefit from any training they may be given. It also has the effect of weeding out those whose skill may lie more in craftsmanship than in purely intellectual attainments. On the other hand, it will let in those whose intellectual ability, in the sense of being able to clear these educational hurdles, is high but whose ration of practical ability may be less generous. The ability to pass such examinations as the General Certificate of Education is not possessed by all those with special aptitudes for skill and craftsmanship, particularly of the kind indispensable in the labor. atory animal house.

All sensible experimental biologists pay lip service to the value of good animal technicians and many genuinely believe what they profess. It is more difficult, however, to convince some of them that the absence of an educational qualification, such as the General Certificate of Education, should not automatically condemn technicians to a lower category in the technical hierarchy. On the other hand, employers have a right to expect that the absence of qualifications, such as the General Certificate of Education, shall be compensated by the possession of relevant alternatives in full measure. If it is undesirable that future animal houses be staffed with grammar school alumni lacking aptitude for animal work, it is no less undesirable that the training of animal technicians shall be so little exacting that it will admit those who are incapable of the high standards required.

The Animal Technicians Association provides training and holds examinations for its members and grants qualifications of a standard believed to be fully sufficient for the purpose. Employing bodies should, in their own interest, examine this standard, so that they may either endorse it as it exists, or urge that it be modified in a direction that will make it acceptable to them; and when this is done they should accept it. In this way, and in no other, will they ensure a supply of good animal technicians for the future, and make possible the supply of good laboratory animals.

\section{CARNEGIE TRUST FOR THE UNIVERSITIES OF SCOTLAND}

\section{REPORT FOR 1955-56}

7 HE fifty-fifth annual report of the Carnegie Trust for the Universities of Scotland* records a continuing growth in the number of applications for assistance in the payment of class fees during the academic year $1955-56$, on which $£ 26,867$ was spent, compared with $£ 24,232$ in the previous year, 1,720 benefiting compared with 1,502. In view of counsel's opinion that the trust deed embraces matriculation, laboratory and examination fees as well as class fees in the narrow sense, the Executive Committee is examining anew its obligations, particularly with reference to students who have shown exceptional merit at the university. During the year, $£ 32,177$ was disbursed or set aside for grants for research schemes, and in addition to awards of one fellowship and one senior scholarship, thirty-four scholarships were renewed and twenty-five elected to begin research in October 1956. Of nine grants to members of the staff of universities for study abroad, six went to American universities and similar institutions, mainly for research in surgery and medicine, one to the Institute of Cell Research, University of Munich, one to the Vatican Archives, Rome, and one to the Department of Zoophysiology, University of Copenhagen. Twelve guarantees were made against loss on publication of manuscripts and thirteen Scottish learned societies assisted in the issue of periodical publications. The decline in repayments by former beneficiaries continued.

The report upon the work of investigators under the research scheme during the year refers to substantial improvements in the experimental technique made by A. V. Gold in his study of the de HaasAlphen effect for electrical conductors in a magnetio field. The standard of work of the thirteen scholars in the Chemistry Section was commendably high, and Mr. H. M. MeGeachin has made important contributions to experimental technique and to structural analysis in X-ray investigations of rhamnose monohydrate and sucrose crystals which will be of great value in resolving the problems of sugar crystallography. Five scholars at St. Andrews are studying the kinetics of the thermal decomposition of derivatives of benzyl and some organic iodides, using a mass spectrometer to detect intermediate free radicals. Especially emphasized are Mr. Dennis Mackay's study of the flow of cations through a cationic exchange resin, Mr. Donald Mackay's study of free radicals in heterocyclic systems, Mr. I. D. R. Stevens's research on the reaction between nitrogen tetroxide and cyclohexane in the presence of bromotrichloromethane, Mr. M. Los's work on the synthesis of heterocyclic systems, particularly compounds analogous to the betaines, in which he discovered a new method for the reduction of azo-compounds with hydrazine, and that of Mr. F. Stevens which has demonstrated the existence of certain immunological relations between the serum proteins and those present in egg-white.

In the Biological Section reference is made to A. D. Berrie's work on the parasites of freshwater fish, to Helen G. Kerr's studies at Millport of the

* Carnegie Trust for the Universities of Scotland. Fifty-ffth Annual Report (for the year 1955-56) submitted by the Executive (Edinburgh : Carnegie Trust for the Universities of Scotland, 1957.) 